\title{
Crafting nature: the Galapagos and the making and unmaking of a "natural laboratory"
}

\author{
Diego Quiroga ${ }^{1}$ \\ Universidad San Francisco de Quito-GAIAS, Ecuador
}

\section{Introduction}

Understanding of nature is shaped by a series of schemes, perceptions and emotions constructed and produced in regions where the accumulation of academic, economic and political capacity allows these definitions to emerge and be exported to the rest of the world. Those who live in areas that are the focus of international attention, such as the Galapagos Islands, must accommodate the structuring effects of these accumulated constructions. Within this context, certain groups including international NGOs, national governments, scientists and the mass media, seek to consciously or unconsciously manipulate the moral, aesthetic, motivational and cognitive structures of the local residents. Biodiversity, conservation, and sustainable development are part of an increasingly globalized understanding of nature and our relationship with it. The diffusion and expansion of these schemes has resulted in the creation of institutions that mediate the relations between humans and their environment.

One such institution is the nature reserve. The establishment and definition of protected natural areas, both terrestrial and marine, are becoming an increasingly important tool for controlling human activities as well as for mediating people's interaction with certain zones and regions that from a globalized perspective are considered to be pristine and threatened. To conserve and protect these fragile ecosystems, governmental and nongovernmental organizations such as the IUCN, TNC, and WWF among others, have classified and managed animals, plants and natural areas based on their importance for a conservationist's model. Protected zones, as well as the laws and regulations that constitute them, and accompanying management practices, mediate the relationship between people and their natural surroundings and, in many parts of the world, affect not only the lives of those who live within a protected area, but also those involved in its management as well as the visitors and tourists who travel to these areas. Underlining the creation and management of such protected areas is the Western dualism between nature and culture, a vision which distances in an artificial manner human activity from the natural environment and that has been imposed on much of the world (Gillison 1980, Johnson 2000, Shiva 1988). These global matrices prioritize some areas for conservation, and shape, craft and modify not only the legislation and property rights of the residents in these regions but also the perceptions and actions of visitors and researchers who go to these places (Bishop et.al. 2004).

In this article, I discuss and analyze the ways in which different social sectors interact with, and manipulate the global construct of the Galapagos as a "natural laboratory". This construct was first generated by evolutionary science, and then adopted by conservationists to argue for the need to protect the Islands' natural processes. Fisheries and tourism, by contributing to an increase in the population growth, also contribute to the introduction of new species of flora and fauna (Kerr, Cardenas and Hendy 2004, Bremner and Perez 2002). Tour operators and naturalist guides popularize some of the key findings and discoveries of scientists. Darwinian evolution, and other scientific discoveries, have established the cultural context through which tourists understand and experience their visit to the Islands. Guides and guidebooks frame the encounters with the flora and fauna of the archipelago. In contrast to these sectors, some of the local residents, particularly fishermen, have rejected this notion of the Galapagos as a "natural laboratory" and have used most of the conservation symbols and discourses to oppose what they consider to be the domination, control and oppression of residents in the Galapagos.

I will also analyze the discourses produced by a growing local tourism industry. On one hand it shares with the fishermen a deep suspicion of conservationists and the powerful tourist operators that own most of the cruise boats. On the other hand, it uses some of the key symbols and discourses generated by tourism and conservation to gain access to the growing ecotourism market. Galapagos is, thus, a complex social system and these sectors cannot be seen as isolated from one another. Each sector is connected to others through multiple links, and these emotional, institutional and economic ties create a rich, fluid and dynamic social context in which new discourses and strategies are constantly being produced. Each one of the sectors has a different understanding of science and the scientist, and of nature and conservation - understandings which are continuously being negotiated and recreated.

In the second half of the twentieth century, many areas in Latin America and other parts of the developing world were identified as unique and pristine and were dedicated to the conservation of nature, often times motivated by the pressure imposed by the governments of developed nations, international organizations, and large international NGOs. Many of these areas considered to be environmental hotspots have also now become social and political hotbeds (Wilshusen et. al. 2002). Humans have often been viewed as disruptive agents inserted into a pristine natural environment, which is construed as balanced, harmonious

\footnotetext{
1 Prof. Diego Quiroga, Dean of Academic Affairs and Professor of Anthropology, Universidad San Francisco de Quito, PO Box 17-12-841, Ecuador. dquiroga "at" usfq.edu.ec. Quiroga is also at the Galapagos Academic Institute for the Arts and Sciences (GAIAS) in San Cristobal.
} 
and homeostatic (Scoones 1999); a feminine and fragile space threatened by overpopulation and destruction by the native inhabitants. The creation and the management of these protected areas is embedded in power struggles between the individuals and groups that have the capacity to define the management of the area's ecological services and goods and the local inhabitants who reject, ignore or appropriate these dominant concepts often thereby generating novel hybrid cultural models.

During the twentieth century environmentalists promoted an ecocentric discourse - and conservationist practices - that elevated nature above humans and their societies. Restoration and conservation ecology were established as scientific endeavors aimed at maintaining and recreating natural areas and wilderness. In some protected areas, as in the Yellowstone National Park in the United States, the human presence has been systematically erased in an effort to create a quintessential "wilderness" experience. This model of a peoplefree park was replicated in the creation and management of many protected areas around the world (Burnham 2000). Applying this scheme to areas where people live, some traditional economic practices were criminalized and the local residents told to abandon the area or to change their economic activities (Agrawal \& Ostrom 2001, Brothers 1997, MacKay \& Caruso 2004, Peluso 1993, Wilshusen et al. 2002). An ethical code was developed and imposed on the local people that defined previously adequate, productive and reasonable activities as reprehensible and disgraceful. Animals, plants and places were reclassified and given a different significance in the context of evolutionary or biodiversity paradigms, with traditional valuations often being ignored or even disowned. New categories and institutionalized practices were used to define places as "hotspots", "biosphere reserves" or "marine protected areas"; animals and plants as "endemic", "native", "introduced", "invasive", "vulnerable" or "threatened"; and people as "natives", "indigenous", "colonists", or "tourists".

As more protected areas are being established in places where people now live, it is increasingly necessary to design management strategies which allow for the inclusion of local people. In some cases, residents are seen by eco-managers as romanticized noble savages integrated in nature in a harmonious and sustainable manner. In other cases, people are viewed as intruders and disrupters, outsiders and colonists that have few rights to the services and resources provided by nature. Still, they are increasingly identified as collaborators and partners in the efforts to preserve sensitive ecosystems. The main concern for planners and managers thus becomes defining strategies for administering the people living inside protected areas, people who often feel marginalized and resist the regulations imposed on them (Igoe 2003, West et al. 2006, Peluso 1993, MacKay et. al. 2004, Burhham 2000). Kottak notes that problems usually arise when external regulations replace the local or native system, as when traditional property rights are replaced by a foreign system of property rights (Kottak 1999). Like imposed development projects (Escobar 1995), conservation schemes may ask local people to change their conventional practices to satisfy the goals of conservationists. The managers of nature impose moral regimes that are often at odds with local perceptions, land uses and traditional management tactics (Brosius 1999).

Local residents react in different ways to the imposition of conservation discourses (Hall 1988, Adkin 1992, Caroll 2006). Scholars have reported a mixture of responses, that range from rejection, to acceptance, to appropriation and reformulation of imposed discourses, values and understandings. These reformulations mean that there is partial appropriation of some elements of the imposed discourse, and thus the creation of hybrid responses, rather than a complete acceptance or wholesale rejection of local and traditional views (Garcia Canclini 1989).

In many protected areas, tourism has become an important part of the dominant management strategy as it is seen as a way to generate income while maintaining a relatively low environmental impact. As a social phenomenon, tourism shapes and is shaped by cultural systems. For many in western countries tourism agencies define what constitutes a pristine and exotic environment and tourists' perceptions and expectations put pressure on local administrators to conform to their requirements (Errintong and Gewertz 2003, West and Carrier 2004). As some pristine areas disappear, tourism companies manipulate the Western ideal of wilderness to craft a kind of 'refuge'. As indicated by West and Carrier (2004), tourism is not only a cultural process of defining the world but it also includes a series of practices and interventions directed toward the creation of a desirable and idealized destination. Governments, market forces, and conservation agencies shape protected areas in response, at least in part, to the demands of the ecotourist expectations and, in some cases with the express purpose of generating a constant flow of visitors. Ecotourism thus becomes a form of virtualism, a process by which a reshaping of nature takes place not only for the preservation of valued ecosystems but also for the creation of landscapes that conform to Western idealizations of nature (West and Carrier 2004).

Participatory models and strategies need to be developed so that local residents can be included in the management process. These strategies are guided by the need to educate, to achieve consensus, and to empower. Although they represent an important alternative to more traditional top-down management schemes, some of these new strategies have still been criticized for concealing power relations and merely masking the imposition of externally generated agendas (Stirrar 1996). 


\section{The crafting of the Galapagos as a "natural laboratory"}

In places such as the Galapagos, where scientific, conservation and touristic concerns define to a large extent the agenda of governments involved with conservation efforts, the restoration of pristine areas becomes a scientific endeavor guided by our current understanding of the theory of evolution. In the Galapagos, the constructs created and promoted by the tourism industry are saturated with scientific concepts and are closely tied to Charles Darwin's life and ideas. The natural and human history of the Galapagos, with their critical role in the formulation and shaping of the theory of evolution, have lead to their construction as a "natural laboratory" and have contributed to the development of their iconographic character. The tourist industry has utilized the Islands' important place in the Western imagination to turn them into a sort of secular pilgrimage site. Many visitors to the Islands seek not only a better understanding of the great scientific revolutions that have shaped the world, but also a mythical encounter with one of the foundations of modern Western world views.

As is true with other protected areas, the professionalization of the management process of the Galapagos National Park (GNP) and the Galapagos Marine Reserve (GMR) is part of a strategy designed to craft a landscape according to a set of documented assumptions of what the Galapagos was before humans arrived and transformed the landscape. One of the main goals over the last fifty years has been to preserve or, in some cases, to reconstruct the key characteristics that make the islands a unique "natural laboratory". The Galapagos has been at the center of debates about biological evolution and the mechanisms that result in the origin of new species. It has also been the center point of a tourism industry based on the commercialization of the findings of scientist and researchers.

The construct of the Galapagos as a pristine place, and as a "natural laboratory" is the result of a process that began with the narratives produced by Spanish conquerors and explorers, and later by British pirates and American whalers, and finally by Western scientists, adventurers and travelers. Part of the European expansion that started in the fifteenth and sixteenth centuries included the expansion of cartography, taxonomy, and the natural sciences in general, as well as of scientific institutions such as museums, to study and collect specimens from diverse regions of the globe. This desire to control and understand nature grew hand in hand with the creation and expansion of the global economic system, and had its greatest expression in the impressive work of the Swedish naturalist, Carolus Linnæus.

Early visitors to the Islands, including Spaniards and some British pirates and buccaneers (including Dampier, Cowley and Rogers) contributed to a narrative of the archipelago as distant and barren, but also intriguing (Latorre 1992, Preston \& Preston 2006). The pivotal point for such accounts came with Charles Darwin's descriptions of his visit to the Islands and the way that the animals, particularly the mockingbird, the tortoise and later the finches, inspired his reflection on the mutability of species early on in his career (Sulloway 1984, Quiroga 2009). Darwin's reflections and conclusions guided the emergence of the Galapagos as an icon for Western imagery and topography and are a fundamental part of our modern secular cosmology (Larson 2001).

Many of Darwin's followers and opponents subsequently used the Galapagos as a space where the theory of evolution could be contested. During the latter part of the nineteenth and early decades of the twentieth centuries, the Galapagos was a privileged space where institutions and leading scientists from Europe and North America came to study evolution and biology. Creationists and catastrophists like Agassiz and Gunter, as well as Lamarkianists like Bebee, went to the Galapagos to refute some of Darwin's theories and conclusions. Funded by the industrial nations and wealthy patrons such as Walter Rothschild, Vanderbilt, and Astor, scientists and explorers mapped the Islands and collected and classified thousands of specimens for private and public museums and zoos (Larson 2001, Quiroga 2009). It was believed at the time that it was better to have these animals caged in zoos and stuffed in museums than running wild in the Galapagos, where very few people could see and study them and where they would be at the mercy of the small but active groups of colonists living there. During the early twentieth century, as Darwinism became firmly established in the West, scientists like David Lack and American ornithologist Robert Bowman traveled to the Galapagos to explore the mechanisms of Darwinian evolution such as character displacement, adaptive radiation and natural selection. They thought, as Darwin had, that the Galapagos, with its unique geography, its size, and its degree of isolation from the mainland and between the islands, provided the ideal location to answer many of the key questions that were arising from the new and by then dominant cosmology in a natural, undisturbed setting. Each one of these studies contributed to the reputation of the Galapagos as a living and "natural laboratory" ideal for the in situ study of the mechanisms of evolution by natural selection (Larson 2001, Quiroga 2009).

A group of scientists, inspired by the unique geographical and biological conditions of the Islands began to worry about the disappearance of some species such as tortoises and fur seal (a type of sea lion), due to hunting by whalers and colonists. They became interested in protecting the Islands and their endemic species. Some scientists also became aware of the importance of conserving the Galapagos as a "natural laboratory" for conducting research and observing natural processes, as they developed their collections for the benefit of science (Larson 2001, Grenier 2007). In the 1930s and 1940s, conservationists began accumulating political and economic resources and some of them set the agenda for the management of the Islands. Several scientists were contacted by UNESCO, including Julian Huxley, the grandson of Thomas 
Huxley, one of Darwin's main defenders; German ethologist Irenaus Eisbelt-Eisbefleldt; and Robert Bowman. They stressed the need to create a protected area, concerned with what they considered to be the worrisome increase in the number of people living in the Galapagos, at the time approaching two thousands inhabitants (Larson 2001, Quiroga 2009). Pressured in part by scientists and some international institutions, by 1936 the government of Ecuador created a wildlife sanctuary and forbade the hunting of some species, although no official institutions existed at the time to enforce these regulations (Zapata 2005).

Aiming to leave the Galapagos as undisturbed as possible and even to restore some areas, UNESCO proposed declaring the Islands a national park where eco-tourists could enjoy the unique animals and landscapes (Larson 2001, Grenier 2007). In 1959, one hundred years after the publication of the Origin of Species, the Charles Darwin Research Station (CDRS), based in Belgium, was founded. That same year, the Ecuadorian government officially established the Galapagos National Park (the GNP). Although there were some Ecuadorians involved, the GNP was largely established through the efforts of European and some North American scientists, all sharing a global vision of the Galapagos and their importance for science. The original idea, according to Grenier (2007), was that the CDRS would aid and to some extent act in the place of Ecuadorian authorities to ensure the protection of the Galapagos. It was inaugurated in Santa Cruz in 1964 and the government of Ecuador signed an agreement with the Charles Darwin Foundation (CDF), making it the official advisor of the Park. Thus, the goal of protecting the Galapagos was, from the outset, an international effort with little, if any, participation from the local community.

In 1965, a team of British park planners studied the archipelago and recommended tourism as the best way of assuring its economic well being (Larson 2001). It was also around this time that GNP officials began delimiting the Park areas and evicting some farmers from their lands. By 1970, the Ecuadorian government had established the boundaries of the Park and designed 97\% of the Park's territory as a protected area. Guards were hired to patrol it and a top-down management scheme was implemented, with many of the main decisions being made in Quito, greatly influenced by foreign scientists and conservationists. As the population in the Islands continued to increase, the national government, pressured by conservationists, started to restrict and criminalize activities that were part of the quotidian practices of the local population. Many of these activities had until that time been part of the early colonos' practices which included logging of some endemic and native trees traditionally used for construction, as in the case of the matazarno (Piscidia carthagenensi), the use of tortoise meat as a source of food, the fishing of sea turtles and sharks, the use of long lines and agricultural products such as pesticides. The introduction of plants and animals, among other activities, began to be restricted, regulated, and in some cases, forbidden.

In the second part of the twentieth century, the management of nature became more costly and intensive. Energy and labor went in to eliminate introduced species and protect endemic wildlife. One of the first recorded efforts to consciously craft the landscape came from the crew of a boat owned by the American millionaire, Captain Allan Hancock, who transported land iguanas from Baltra to North Seymour Island in order to save the population. Such individual efforts were institutionalized in the late 1960s when the CDRS and the GNP began developing their own programs to manage the environment and the animals. Millions of dollars from international donors, the Ecuadorian government, and from the park entrance fee charged to tourists, have been spent on managing the landscape of Galapagos according to an ideal based on its supposed original form.

Also in the second half of the twentieth century, some key environmental problems were identified and solutions defined according to the existing conservation paradigm. As is true with many protected areas around the globe, the managers and planners of the GNP and the Marine Reserve (the GMR, Fig. 1) have utilized concepts based on a linear command and control management paradigm such as carrying capacity and maximum sustainable yield. During the 1980s and 1990s when fisheries and marine tourism became important economic activities, these management practices that were initially designed for the terrestrial areas were also applied to oceanic and coastal ecosystems. They reflect a static conception of nature, and aspire to maintain, and, in some cases, recreate the conditions that make the Galapagos an ideal site for the study of evolutionary processes and the tourism industry (Walker et. al. 2002). They have eradicated some species of plants and animals and bred and repatriated others to their original environment.

One of the earliest official efforts to manage the marine area of the Galapagos occurred in 1974 with the establishment of the first management plan for the terrestrial GNP. This plan recommended protecting a 12 square nautical mile area around the Park in order to conserve coastal, marine and land species (Heylings and Bravo 2007). In 1984, the Woods Hole Oceanographic Institute presented a technical report for the management of protected marine areas and, two years later, on May 13, the Galapagos Marine Resource Reserve (GMRR), which did not yet has national protected area status, was created (Zapata 2005). In 1992, the management plan for the GMRR was approved, establishing a zoning scheme for the 15 square nautical miles and recommending that there be a special form of protection for the adjacent area up to 80 nautical miles distant (Heylings, and Bravo 2007). The 40 nautical mile law that creates the Galapagos Marine Reserve passed Congress in 1998, and by 1999 the first management plan for the GMR was produced. 


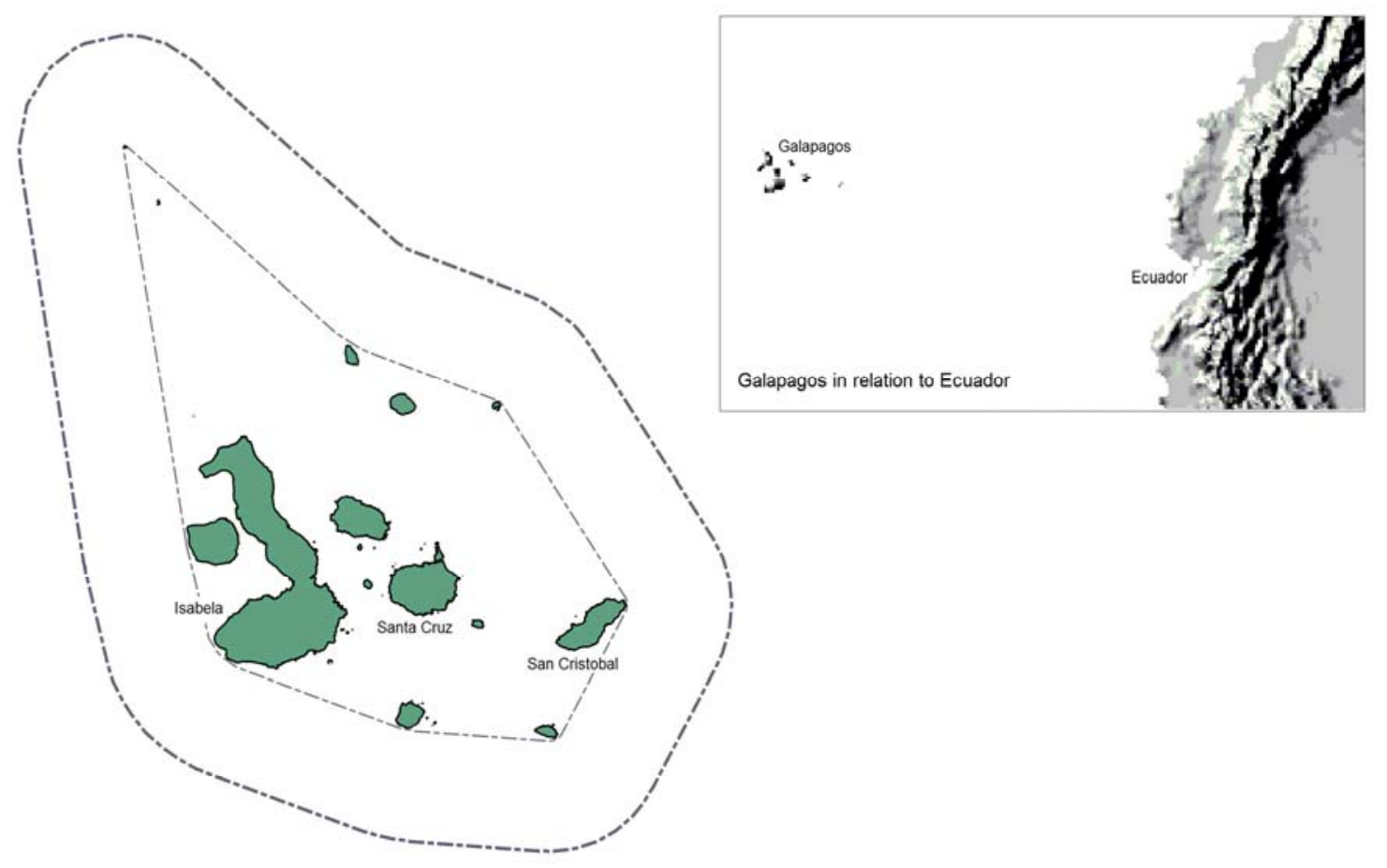

The Galapagos Islands and the Galapagos Marine Reserve

Fig. 1: The Galapagos Islands and the Galapagos Marine Reserve.

The creation of these protected areas and the crafting of environments requires the training of professionals and experts to deal with issues that are selectively made visible by the discourses, research and practices of conservationists in the Galapagos (Escobar 1995). University programs, specialized publications and international and national organizations are involved in producing and supporting managers and planners of protected areas such as the Galapagos. Planners concern themselves with the long-term sustainability of the socio-ecological system; they are usually high level officials from the GNP and the Ministry of the Environment, or they work for the CDRS or other large international NGOs and universities. Managers, on the other hand, are often GNP personnel.

Some of the most successful and renowned conservation programs are those involving the repatriation of tortoises, such as those implemented on Española, Isabela, Pinta, and San Cristobal Islands. On some islands, it became clear that the repatriation of animals from their breeding sites would not be successful unless introduced species were eradicated, resulting in the establishment of massive and expensive goat and pig eradication programs. It is not only anthropogenic factors, however, that have threatened endemic animals. Volcanic eruptions have endangered the tortoise population and have led the Park and the Ecuadorian military to mobilize personnel in aircraft and boats to save them (Nicholls 2007, Grenier 2007). Many local residents resented this type of effort for they feel that compared to endemic animals, humans receive little attention from the Ecuadorian Government.

As a result of all of these efforts, the Galapagos has become well known not only for the large amounts of scientific publications produced about the evolution of its flora and fauna, but also increasingly for the science of conservation and the techniques used to manage protected areas (Santander 2007). The science and techniques of restoration have been developed and institutionalized to become a leading field within conservation biology (Elliot 1997). Although restoration efforts in the Galapagos were successful in different ways, they also caused unexpected consequences in the environments being restored. For example, the removal of goats from some islands such as Pinta, where the tortoise population had been diminished by whalers, pirates, colonists and scientists, created a problem of vegetation overgrowth. At the moment Park personnel are considering introducing tortoises from Espanola to control it.

There are constant threats, despite all these laws, actions and interventions. Planners and managers worry about economic growth, alarming rates of in-migration, increase in illegal and legal fisheries and the growing number of tourists arriving in the archipelago. Often times, institutional weakness and corruption add to the sensation of uncertainty and lack of control over the situation. Probably the major threat at the 
moment is the loss of biological isolation of the Islands as more tourists, colonists and products of all kinds arrive every day. This has compromised the Galapagos' "natural laboratory". Since its discovery in 1535, the Galapagos has experienced the introduction of more than 700 alien plant species in 470 years, or 1.2 species per year, large when compared to the natural arrival rate of one species per 10,000 years (Tye 2006). In 2007, 1,321 introduced species were registered compared to 112 species in 1900 (Tye 2006, Watkins and Cruz 2007).

Efforts to contain the flow of insects, animals and plants and to restore the ecosystems to protect the "natural laboratory" have focused primarily on the archipelago's emblematic animals such as tortoises, marine birds and terrestrial iguanas. These efforts have created an increase in conservation funds flowing from the GNP and various NGOs. Government spending has also been increasing; it is currently the second largest source of income in the Islands after tourism (Watkins and Cruz 2007). NGOs and other conservation organizations have increased in number from three in 1990 to sixteen in 2006, and the funding allocated to them has also increased.

\section{Tourism and the marketing of the "natural laboratory"}

A source of income was needed if the environments of the Galapagos were to be preserved. Tourism was conceived as the natural ally of conservation in the early stages of setting up the GNP. UNESCO and other organizations thought tourist guides and operators could provide funds for conservation and guarding wildlife and habitat from fishermen and others. For many tourists, the meaning of the Galapagos is largely derived from popular science. Two of the most popular books that place the Galapagos as an important point in Western imagination are Beebe's 1924 work, Galapagos, world's end, and more recently, Jonathan Weiner's 1995 Pulitzer-Prize winning book, The beak of the finch. The latter popularized the work of Peter and Rosemary Grant, whose studies documenting the mechanisms of evolution have amazed the scientific community since the 1970s. Scientific documentaries, popular press articles, leading popular science magazines and TV programs on the Discovery Channel and Animal Planet have been important not only in emphasizing the archipelago's connection to the theory of evolution, but also in shaping the image of the Galapagos as a pristine natural paradise. A recent BBC/National Geographic documentary, Born of Fire, (2007) summarizes these Western narratives well: "Galapagos are no ordinary Islands, a mysterious prehistoric world, a landscape that profoundly influences life; these islands are plumbed directly into the heart of the Earth." All these constructs are the product of a multimillion dollar industry involved in the documentation of the remaining refuges of 'wild' nature, and highlight how scientists and ecologists defend and protect them. Rarely shown are the towns and cities where people live, or the existing conflicts and tensions occurring in and around protected areas.

Countless narratives, films, articles and brochures generate this interest in the Islands and increase the appeal of the emblematic species (Ospina 2006, Grenier 2007, Quiroga 2009). Of all of the endemic animals in the Islands, the giant tortoises are some of the best known. Their historic importance for the development of the theory of evolution, their unusual size, and their endangered status make them a key reference point for conservationists and scientists around the world. It was their appeal as an emblematic species, however, that cost them dearly when scientists and wealthy collectors removed them from the Islands during the last part of the nineteenth and early twentieth centuries and, more recently, when fishermen killed them as a symbolic act of rebellion against the GNP and the CDRS. The most famous of these tortoises is Lonesome George, the last living Pinta Island Tortoise (subspecies Geochelone nigra abingdoni) and an emblem for the work of the GNP and the CDRS. Major efforts have been dedicated to perpetuating his subspecies, and many tourists visit the CDRS with the expectation of seeing this famous tortoise (Nichols 2006).

The tortoises are just one of the animals in the Galapagos that exemplify the complex relations between science, conservation and tourism. Some of the most frequently photographed animals, such as boobies, marine and land iguanas, sea lions, frigate birds, tortoises and finches are the same animals that are most extensively studied by scientists, whereas the animals that are not emblematic, such as insects or microorganisms, tend to be less studied (Grenier 2007). The influence of tourism on science can shape, to some extent, conservation strategies, as West and Carrier note (West and Carrier 2004).

Ecotourism not only defines important aspects of nature but also reshape them to conform to a virtualism generated by Western models of wilderness and nature (West and Carrier 2004). This reshaping underlies what West and Carrier see as a "contradiction in ecotourism: its tendency to lead not to the preservation of valued ecosystems but to the creation of landscapes that conform to important Western idealizations of nature through a market-oriented nature politics that results in the creation of a product that fits the [ecotourist] market needs" (West and Carrier 2004, p.485).

The importance of science for tourism is reflected in some of the strategies used by large and small tour operators and tourism agencies that sell Galapagos packages. Tour operators frame tours within the context of the theory of evolution, the life and deeds of Charles Darwin and of the existing efforts and findings that support his famous theory. Many boats have names such as the Beagle, Darwin, Finch and Evolution and connect their touring to Darwin's saga. Guides also play a critical role in the contextualization of visitors' experience as they explain the morphology and behaviors of animals and plants based on the principles of 
genetic diversity and natural selection. Guidebooks and popular scientific accounts of Darwin and his followers read by tourists before, during and after their trip are also part of this process of molding the visitor's experience in the Galapagos. This characterization of the Galapagos as a people-free "natural laboratory" ideal for the observation of the unfolding process of evolution is a strong attraction for educated, relatively well-off travelers around the world and it has become a multimillion dollar business, with the number of tourists increasing every year.

Tourism started with the arrival of private sail boats to the Islands during the early part of the twentieth century. However, it was only in the 1960s that the local population first became involved in tourism as fishermen began taking tourists and visitors to different sites to view tortoises, iguanas, sea lions, birds and, more recently, sharks and marine turtles. Tourism on a larger scale started when investors from the mainland and abroad began taking note of the opportunities the archipelago had to offer and larger cruise boats started taking visitors to the various islands. In the 1960s and 1970s the 'Galapagos model' was created; tourists were to travel aboard 'floating hotels' from one island to the next, mainly to try to reduce operational costs and to a lesser extent to minimize the effect on the islands as fewer people would be staying in the towns (Grenier 2007). In the 1970s, an increasing number of tourists began to arrive at this modern secular pilgrimage site and the GNP started regulating the places that tourists could visit. The Park also began training tour guides to control tourists and protect the natural areas. As a part of this new emphasis on tourism, an airport was opened on Baltra Island, using the airstrip built by the United States during WWII, and some years later, on San Cristobal Island.

Although in general tourism and conservation have been close allies, the threats of an uncontrolled growth in the number of visitors to the Islands have become a concern. In the 1974 GNP Management Plan, the growth of tourism is criticized. The CDF suggested a maximum of 8,800 tourists per year based on a system of quotas per tour boat, but by 1979, 11,765 tourists were visiting the GNP. In 1981, a governmental commission specified 25,000 per year as the maximum sustainable number of tourists. Although the numbers remained under 20,000 visitors per year until 1986, that year they rose to more than 26,000. In 1984, a second management plan set a maximum carrying capacity of 41,767 tourists annually, but this number was also quickly surpassed (Grenier 2007). In 1994, 53,825 visitors traveled to the Galapagos and in 1999 the number rose to 66,053 (Heslinga 2003). In 2007 the number of tourists exceeded 170,000 according to figures given by the National Park. In 2008 there were nearly 1,000 hotel rooms accommodating more than 2,000 tourists a day. Most tourists stay in Santa Cruz but the number of hotels is also growing rapidly in San Cristobal and in Isabela (Ordonez 2008). In 2007, UNESCO placed the Galapagos on the 'endangered' list and blamed the uncontrolled growth of tourism as one of the main challenges for the sustainability of the islands.

Not only does the number of tourists keep increasing, but, as Watkins and Cruz (2007) suggest, there is a change in the type of tourists. More and more, a generalized nature tourist is visiting the Islands who is no longer attracted to the Galapagos, per se, but is looking for any destination where she can be in touch with "nature". Furthermore some visitors are going to the Islands for reasons other than to observe nature; some go to surf, kayak, and even skydive. There has also been an increase in the number of Ecuadorian tourists visiting the Galapagos as the dollarization of the national economy has generated higher incomes for the national population. These new trends worry planners and managers - as the Galapagos is redefining itself as a major destination, the flow of tourists might become more difficult to control and more destructive to the natural environment.

One reason that explains to some extent why the total number of tourists has not been regulated is that the GNP and other local governmental and nongovernmental institutions such as the CDRS are partially dependent on the money they receive from the entrance fee paid by tourists. Total revenues from this fee increased from US\$5.5 million in 2002 to US\$10 million in 2007, resulting in a near doubling of the money gained by local institutions (Oleas 2008). The GNP tried unsuccessfully to control the increase in the number of visitors by setting a system of quotas on the number of tour boats in operation and of berths per boat. Between 1990 and 1996, when supposedly no new permits were issued, the number of boats increased by $22 \%$ and the number of beds by $42 \%$ (Grenier 2007). Although the number of tour boats and berths has not increased over the last few years, there has nonetheless been an increase in the number of visitors as boats are shortening the length of their itineraries and, on some days, have two groups booked for the same boat. Increasingly, tourists are staying in hotels and in houses on the various islands and using the local facilities and services. Park managers have found that not only are there no plans to stop the increase of tourist flows to the towns, but that local politicians and other sectors are hoping that this kind of tourism will fuel local economies.

The connections between conservation and tourism has created the Galapagos Paradox, by which the appeal of the Galapagos is based on its marketing as a pristine, people-free "natural laboratory", but at the same time the success of tourism is creating unpredictable flows of people and other organisms that undermine the unique terrestrial and coastal environments. The efforts of planners and managers to sustain the force of the global economy and of global trends depends on their capacity to hide from visitors the negative 
effects of tourism, while maintaining the ecotourism "bubble" (Epler 2007, Grenier 2007). ${ }^{2}$ To the extent that conservation and restoration can guarantee tourists' encounters with "untamed" nature, for many western travelers the Galapagos will remain a wonderful and pristine wilderness where one can not only experience an intense encounter with wild animals but also understand the processes of biological evolution.

One of the most worrisome consequence of expansion and growth of all kinds of tourism and one that has been to some extent hidden from tourists is the ever expanding number of migrants arriving to the islands and their negative effects on the environment. From 1974 to 1982, the annual population growth rate was 4.9\%, 5.9\% from 1982-1990, and 6.7\% from 1990-1998. The expansion in the 1980s and 1990s of fishing and tourism, and especially of locally-operated tourism, has been one of the main causes of population growth in the Islands as migrants arrive to satisfy the expanding demand for labor. Opportunities began to arise for people who were not necessarily highly qualified or knowledgeable (Grenier 2008) and employers began hiring more immigrants, who often did the same jobs as local residents for lower pay (Henderson, Zurita et al 2005 in Watkins and Cruz 2007).

So far most plans and regulations have failed to stem immigration. Planners and managers have tried, without much success, to control it. The 1998 law regulates who can live permanently and invest in the Islands, stating that "permanent residents" are people born in the Galapagos, those who have been living there for more than five years before the establishment of the law, those who have at least one parent from the Galapagos, or those who have married a permanent resident. Despite this law, Galapagos has grown at a rate that is almost three times greater than the national average. Population growth has also resulted in an increase in the number of vehicles, which not only creates pressure for increased development of infrastructure (Kerr, Cardenas, and Hendy 2004) but also for the need for more fuel to be imported from the mainland.

\section{The local inhabitants: appropriations, conflicts, tensions and responses}

The first colonists to arrive to the Galapagos were mainly interested in agriculture. In the nineteenth century, farms were initiated in the highlands of San Cristobal, Floreana and Isabela. From their beginnings the local inhabitants saw the Galapagos as a barren land which, through hard work and an enterprising mentality, could be developed and made productive. Individuals like Juan Manuel Cobos explored the various ways that profits could be made. Orchilla (red lichen used as a dye), guano, cattle, sugar cane and later fishing were all part of the formula evolved by colonists to produce development and wealth. Cobos named his hacienda "El Progreso," reflecting the late nineteenth century marriage of capitalism and technology. According to this pragmatic and utilitarian model of nature, animals and plants are conceived as being either useful and edible or irrelevant and undesirable. By the middle of the twentieth century the economic importance of fishing had grown, slowly attracting people down from the highlands to the ports and the drier and lower littoral zone. A type of grouper fish (Mycteroperca olfax), locally named Bacalao, is consumed as part of fanesca, a soup eaten during Easter Week on the mainland of Ecuador. It became an important source of income for the local colonists. Fishermen also caught turtles, sharks, lobsters and other marine species to be sold on the international markets. For many of these people the mainland is their main point of reference; they maintain a pattern of consumption and a living standard that reproduces many of the cultural patterns found on the mainland. Over the last forty years, much of their lifestyle is sustained by the influx of tourists.

As tourism and conservation became fused in the globalized discourse of ecotourism (which was presented as the solution to conflicts in the Galapagos), many of the activities of the local residents were restricted and in some cases criminalized. The local fishermen and other residents felt that they were losing control of what they considered to be their living space. Their dissatisfactions were channeled and to some extent generated by the fishing coops, which to the dismay of conservationists, have the promotion of fishermen's interests as their main purpose, at times leading to organized protests and strikes against the GNP and the CDRS. The leaders of the fishing coops and local politicians saw the coops as a valuable tool for furthering their political agendas. In 1983, the first coop was created in San Cristobal, followed by one in Santa Cruz in 1993, another one in Isabela in 1995, and a second coop in San Cristobal in 1996 (Zapata 2005). Through these groups, fishermen were able to capture their sector's feelings of frustration and to mobilize people against conservationists, their institutions, their symbols and what they perceived to be increasingly powerful external control of the islands.

Those fishermen who felt particularly victimized by shifting power dynamics in the Islands presented strong opposition against the top-down style of management and administration. Tensions between the GNP and the fishermen were largely the result of the strengthening of the latter's political and economic power from the 1960s. Technological changes, which included the introduction of fiberglass boats, outboard engines, and the hookah (a compressor that feeds divers with air through a hose), meant that fishermen were able to reach distant fishing spots at a lower cost and could dive deeper to increase their lobster catch. With these new techniques, fishermen began responding to the call of Southeast Asian merchants who came to the

\footnotetext{
2 The "ecotourism bubble" describes the process by which social relations that make possible the tour operation and the appreciation of nature are excluded from the view of the clientele (Cohen 1988; 2002; MacCannell 1973).
} 
Islands in search of sea cucumbers (Isostichopus fuscus). These delicacies were already depleted along the coast of mainland Ecuador; fishermen in the Islands were now being offered credit and the chance to gain a relatively good income from them.

The inevitable depletion of sea cucumbers led to political conflicts between the growing fishing sector and frustrated Reserve managers. As sea cucumber fishing boomed, people migrated from the mainland attracted by the money that could be earned by diving for these echinoderms (Bremner and Perez 2002). At the beginning of the 1990s the GNP set a limit of 550,000 sea cucumbers per year. But with no way to monitor the fishery, the Park's quota could not be enforced. They were quickly surpassed as foreign demand was sustained. In August of 1992, as a result of pressures from the CDRS and the GNP, government authorities banned the gathering of sea cucumbers altogether. This measure was not well-received by the fishermen, who had made unprecedented amounts of money that year, much of it squandered on alcohol and prostitutes and used to pay off debts. In one of the most radical responses to the Park and the Station, seven dozen tortoises were killed on Isabela Island. This was one of the first of a series of strikes and demonstrations by the pepineros, as the sea cucumber fishermen are sometimes called (Grenier 2007). In 1994, faced with strikes and threats and the closing of the airport in San Cristobal, the Park opened the fishery again and tried to impose new controls.

Neither victims nor villains, the fishermen and other local people of the Galapagos have negotiated management measures in diverse and even creative ways with institutions such as the GNP and international and national conservation organizations. These negotiations have resulted in the transformation of the natural and social environment in ways that are often at odds with the goals of these organizations and with the conservation of the islands.

As the pressure placed on marine resources began to increase, planners and managers started to monitor and control the marine area and to create the institutional structure that would allow them to administer those who profited from marine resources. In the 1990s, with the conflict between fishermen and conservationists at its high point, the GNP and the CDRS began examining ways to ease tensions and strengthen the governance of the Galapagos. Foreign experts in conflict resolution were hired and a comanagement group known as the Grupo Nucleo was created. This group was composed of members from the conservation and science, tourism and fisheries sectors as well as GNP officials. After months of deliberation the group created a management plan for a new and bigger reserve. These efforts culminated in the passing of the Special Law for the Galapagos in 1998 and the creation of the 40 nautical mile Galapagos Marine Reserve (GMR) alongside a management plan. Part of the plan included the creation of two management bodies: the Participatory Management Board (PMB) and the Inter-institutional Management Authority (IMA). Industrial fishermen from mainland coastal cities such as Manta, who until the creation of the GMR had been coming to the Galapagos to fish for tuna and other pelagic fish, were excluded from the discussions despite their opposition to the creation of the new 40 mile Reserve limits.

With the creation of the PMB, the Galapagos instituted, at least in theory, a negotiation system based on consensus and agreement. Some topics that were not agreed upon by the Grupo Nucleo such as the zoning of the coastal regions, the permitted fishing gear and vessels, and the fishing calendar had to be re-negotiated in the PMB (Zapata 2005). The PMB consists of representatives from five stakeholder groups (tourism, fishing, guides, GNP and the CDRS representing science and conservation) which must arrive at a consensus on issues such as the management of sea cucumber and lobster fisheries. If an agreement cannot be reached, the issue must be resolved by the IMA, which has representatives from all of the sectors, but is controlled by the government. The PMB has allowed greater participation of the local stakeholders and has empowered the fishermen, facilitating their participation in the decision- making process.

The creation of the PMB, however, did not resolve all conflicts, or violence. Tensions have continued and in 2000 fishermen on Isabela Island burned GNP offices and threatened to kill the Park Director, who was consequently forced to hide in the mangroves. Violent strikes occurred in 2003 and 2004 when the fishermen took over some of the visitor sites. Fishermen and some other local people waving machetes and knives threatened the Station and the Park officials. Park gates in Santa Cruz were blocked and CDRS scientists and managers had to flee by boat while some Park officials escaped using secret routes. These recurrent disputes have raised questions about the success of the so-called participatory management scheme. Heylings and Bravo, for example, conclude:

The results from the evaluation show that the Galapagos co-management process performs well, in design and in practice, in terms of strategic vision, participation, empowerment, consensus orientation and resilience. The process performs less well in terms of responsible representation, equity and credibility. The process is threatened by the lack of a policy framework governing rights of access to the resource, and by the perceived efficacy of an alternative strategy of direct action to influence the decision-making process." (Heylings and Bravo 2007: 205).

Many of the issues, however, are not negotiated in the PMB but more directly, whether in the streets during a fishermen strike, or in the offices of high-ranking Ministry officials in the case of the influential tourism entrepreneurs. 
If the success of the board is to be measured by the number of conflicts amongst stakeholders during a particular time, one can say that the PMB has been partially successful during periods of increased tensions and conflicts (from 2004-2006). Tensions were followed by a period of relative calm in 2007-2008. One of the problems with the management of the GMR is the large number member institutions, and the overlap in their functions. Complexity and the difficulty of coordination make leadership, vision, and planning difficult (Watkins and Martinez 2008). In addition, the effectiveness of the PMB has been weakened by the more recent shift in emphasis from fishing to tourism.

If one were to measure the success of the PMB on the basis of the long- term sustainability of the exploited coastal resources, then one must conclude that it has been unsuccessful, since species such as the sea cucumber have been decreasing every year. In the case of lobsters, the management strategies, which include a fishing calendar, the zoning system and regulations of size and total allowable catch, have produced more encouraging results. Participatory and consensus-based systems often hide complex power relations and ignore non-formal mechanisms used by the actors to achieve their goals (Stirrat 1996). For fishermen, the failure of the PMB is due to the undue power of conservationists and large tour operators. They feel that they are at a disadvantage in the PMB as the conservationist agenda is usually supported by the CDRS, the guides, the tourism sector and the GNP. These sectors are thus able to define the agenda for management and dictate appropriate practices for local people. Part of the fishermen's skepticism about the workings of the PMB also has to do with the sense that the members of the coops are rarely consulted by the board. From a management point of view, the inclusion of fishing coops in the PMB has been more instrumental in increasing the political visibility of coop leaders than it has in improving the commercialization, processing or production techniques of fishing. Fishermen complain that in 1998 when the formal zoning of the GMR was established as part of the so-called "participatory process" the conservationists gained control of the Reserve thus limiting fishermen's access to the marine area. Some older fishermen feel especially frustrated with the zoning system. As Carlos Ricaurte, the founder of one of the fishing coops, explained: "I get very upset every time they mention the zoning of the Reserve for we fought for the GMR but now it is other people who benefit from it" ${ }^{3}$.

Another source of uncertainty and tensions, which also challenge the efforts of planners and managers to maintain a pristine Archipelago, is the influence of political parties in the PMB. By the end of the 1980s, as a result of strikes and demonstrations, the Galapagos was able to elect two representatives to the National Congress. The appointment of these two representatives meant that different political parties were now establishing relationships with diverse local sectors. Candidates and representatives could gain votes by supporting the fishermen's cause and that of other local groups that felt marginalized by the policies imposed by conservationists. The political instability of the central government in Quito over the last ten years and the frequent changes in the nation's presidency and in the Ministry of the Environment has also affected the stability of the Galapagos. Between 2004 and 2006, 12 GNP directors were appointed to the post, with most of the changes having less to do with technical considerations or the appointee's qualifications, then with political struggles at the local and national levels. These politicians have been rousing the local population against conservationists and large tour operators who are portrayed as being a sort of mafia that plan and plot against the interests of permanent residents, and that profit considerably from the reputation of the Galapagos.

As I have noted above, although fisheries are important for many, they are losing importance as the main economic activity as the marine resource grows scarcer. Thus it can be said that to some extent the disappearance of resources results from the increase in the number of fishermen, and not from the success of the management systems; diminishing marine resources have led fishermen to pursue other economic activities and thus be less concerned with access to these resources. Many fishermen are now looking for ways to become more involved in tourism.

Fishermen believe that they have some ownership of the Reserve; they claim that although they know the GMR best, and are the ones who fought for its creation, they are not the ones profiting from it. Restrictions have been placed on different fisheries and types of equipment. What is more, obstacles are often placed in their way when they attempt to shift to new economic activities. This, they argue, is evidence of the fact that other sectors want them to disappear. Many fishermen feel that some of the existing mechanisms, such as the PMB, are to a large extent irrelevant for solving the most pressing issues. They believe that powerful businessmen in the tourism sector can easily access high-ranking government officials in Quito, and thus that many decisions about tourism quotas and other matters are made without their consultation. For many fishermen, the idea of preserving and reconstructing the Galapagos as a "natural laboratory" is nothing more than a scheme to further the personal interests of conservationists and tour operators. They raise millions to "save" the Galapagos, but little of that money, some of the leaders in the fishing community complain, reaches the people or the environments for which these funds are supposedly collected.

Fishermen often are skeptical of words such as "consensus" and "participation" and feel that the Reserve's zoning has to a large extent worked against them. They think that both the zoning system and the PMB are mechanisms that delegate control of the Reserve to other institutions. The regulation of fishing gear

\footnotetext{
3 "Se me ponen los pelos de punta cuando pienso en la zonificación pues nos engañaron nosotros peleamos por la reserva y ahora se benefician otros como los del sector turístico."
} 
is another battle that they feel that they have lost. After the creation of the GMR, for example, there was a long fight for the use of longlines. When the fishermen were told not to use longlines because their real interest for using them was to capture sharks, they reacted with strikes. In a study of the perceptions of fishermen, Finchum (2002) notes that:

Conservation funding has been used to hold workshops with fishermen, to inform them of the decision-making process, to support institutional strengthening of the fishing cooperatives, and to provide training. Despite these efforts there is considerable resistance within the fishing community to acknowledge the changing role of the GNPS and the CDRS. Likewise, although the GNPS and the CDRS have tried to improve information sharing and support of fishermen, there is still a need for long-term planning that gives some degree of economic security to fishermen and their families.

Among the fishermen there is little support overall for the management actions proposed by the CDRS or the GNP and there exists a lack of trust which has increased despite the creation of the PMB. Many feel that the PMB is no longer a relevant institution. Finchum (2002) maintains that there are discordant beliefs held by fishermen; they want to support conservation efforts but when they are asked about a specific animal or measure they are not always supportive of these efforts.

Another major source of concern for fishermen is the unequal application of laws. They argue that those powerful, wealthier and better-connected businessmen in the tourism sector are not punished when they violate the law. For example, despite the existence of a law that states that whenever a new boat enters the Reserve an old boat must be removed, this rarely occurs for tour operators. Fishermen, in contrast, are forced to comply with this regulation when they want to replace their small fishing vessels. Large tour boats, the fishermen contend, bring illegal workers from the mainland, usually unchecked by authorities. Similarly, they feel that industrial fishermen are not treated with the same severity as the local fishermen. Local fishermen told me, for instance, that the Park does little if anything to stop industrial boats from fishing illegally at night within the Reserve. Fishermen claim that at night the sea mounds, some of their preferred fishing spots, seem to be floating cities, full of lights from the industrial boats fishing illegally.

Fishermen question not only the capacity and willingness of managers to control infractions but also the science practiced by the CDRS. They feel that the scientists, who are often foreigners, do not understand their needs and concerns. They are also skeptical of the reports that scientists produce, which influence and shape the decisions of managers. They feel they are the ones who truly understand the marine environment, based on their own knowledge and understanding of the oceans, which they argue is far superior to that of the scientists. This negative view of the CDRS contrasts with the view that tourists have of the Station. As indicated by Grenier (2007), only $2 \%$ of foreign tourists have a negative view of the Station, a result in part of the successful publicity campaigns organized by the CDRS. When asked if scientists have a lot of power many people (46\%) agreed, and when asked if scientists are concerned about the people, 50\% replied that they do not show any concern for people. The majority felt that scientists showed disdain for popular knowledge (Quiroga and Ospina 2009). It is on Isabela where the people have a more practical view of nature and have been least influenced by the global paradigm of science and evolution (Quiroga and Ospina 2009).

The rejection of and opposition to the global discourse of conservation among the fishermen of Isabela are also manifested in acts of rebellion against the dominant discourse. Illegal shark fining is an industry that has become the major source of income now that many of the other alternative fisheries have decreased in importance. This illegal fishery is not only a lucrative endeavor but also a way for some fishermen to show their opposition to the pressures imposed by the conservationists and the local authorities. Fishermen use banned fishing gear such as longlines and nets to kill sharks and cut their fins which they then sell to international traders. The increasing demand for shark fins by the Asian markets has fueled an illegal industry, especially it is rumored, among the fishermen of Isabela.

The way that emblematic animals are used by the Park, the CDRS and large tour operators is often criticized by fishermen. Fishermen feel that many of the conservation NGOs working in the archipelago profit from marketing schemes which are based on the idea that the Islands must be saved from the destruction caused by the local people. "Lonesome George here, solitary George there, that is the best business that the conservationists have invented," claimed one fisherman when asked about Lonesome George by a group of my students during a presentation. Many fishermen express this sentiment as they encounter structural and institutionalized forms of discrimination. This reflects a lack of trust that the fishermen and many of the local people have of the conservationists, GNP managers, and the tourism sector. The strategies of control on the part of the eco-managers are thus revised and questioned, and often in a burlesque manner, in rituals, jokes, public speeches and strikes.

The fishing sector is not a homogenous one. Many of the fishermen arrived in the 30 years. Presently some fishermen work in the public sector and others are merchants or work in tourism (Castrejon 2008). Those fishermen descended from the original settlers consider recent migrants to be less deserving of the privileges that older residents have had. There is a sense among the people whose families came to the Galapagos before the 1940s and the 1950s that they are the "real" Galapagueños or nativos, and that even those permanent residents that came after them should not have access to the same privileges. Older residents 
consider themselves to be worthy of greater rights, contending that their ancestors lived in the Galapagos without access to basic services and when communications were precarious; they suffered in the process of the taming of the Galapagos. These residents argue that although many of the first settlers were criminals and convicts, that these people left the Islands when the original haciendas collapsed; they are descended from the few "good families" that stayed in the Islands and worked hard to improve the situation for everyone. Many of these "good families," who were involved in farming and fishing have a sense of entitlement to the Islands and feel that they can reject externally fashioned plans and projects.

Although some of the local residents consider themselves to be natives, from the point of view of many conservationists they are all introduced and foreign to the Islands and like invasive species, they pose a threat to the conditions that make the Archipelago a "natural laboratory". The Galapagos has no truly native inhabitants who were there before the arrival of the Spaniards in the seventeenth century, and even the nativos are recent arrivals compared to the populations of other islands in the Pacific. No romanticized view of the local population, therefore, can be part of the dominant construct of the Galapagos and until recently the only prevailing image on the part of conservationists has been that of people as introduced predators. This view is especially strong in the isolated context of Isabela, where people appropriate this discourse to build an antiheroic identity which they evoke in acts of protest and to frame their illegal actions. Fishermen in Isabela talk about themselves in a somewhat sarcastic, but proud, way as being pirates and outlaws and refer to their island as the Wild West of the Galapagos.

For the older colonists, the bitterness and disdain towards conservationists who view the Galapagos as a people-free "natural laboratory" is based on memories of past events. Many local people feel that the Park and the Station are more concerned with the well-being of the Islands' animals than of the people who live there. Local people are aware that millions of dollars are poured into the Galapagos every year to protect and conserve the area, and yet, most of that money, they argue, goes toward paying salaries and studies that do little to benefit them.

Fishermen's protests have generated changes in the strategies used by the managers and planners from the CDRS and other members of the conservation sector, for whom it became clear that the model of conservation could no longer ignore the local population. New strategies and discourses were introduced by Western experts and professionals who sought to take into account the needs and concerns of the local people. Based on novel concepts such as empowerment, communal participation, and gender equality, conservationists have implemented new strategies to protect nature (Stirrat 1996). Once social and economic issues became contextualized as environmental concerns, financial resources coming from international NGOs, foreign governments and other organizations to solve such issues increased, becoming one of the most important financial flows to the Islands. The CDRS has transformed its practices and discourses and has been involved in many programs with local residents. Publications and articles dealing with social and management themes are increasing as people become more concerned with social conflicts and political, demographic and economic issues (Santander 2007, González et.al. 2008). The new formulas and models proposed to solve conflicts include education programs, assistance for fishermen and women's organizations to start their own businesses and the creation of fish processing centers.

Far from being passive actors in this system of control and power, fishermen are constantly negotiating and obtaining small triumphs in these daily battles. They have learned how to access material and social resources and to obtain benefits that other sectors do not have. Using their key position in the socio-political system, they have benefited from financial support from NGOs and international aid organizations, securing funds to transform their fishing boats into tour boats, studying to be dive masters, and obtaining jobs and scholarships for their children to attend college. Fishermen have thus been able to manipulate the system in order to attain partial benefits from a structure that has been at times insensitive and even hostile to their needs and concerns. They have the power to threaten the image of the Galapagos as a pristine and natural place and in so doing they can obtain benefits from NGOs and others who want to promote the idea of the Galapagos as a harmonic and pristine social and natural environment.

The creation of alternatives to fishing and the movement of fishermen to the tourism sector as dive masters, managers of sport fishing operations and day tour operators have now become major concerns for some Park planners and managers. With tourism becoming more important from an economic point of view, the nature and reasons for conflicts have changed. The latest disagreements are not about the right to fish more or about the types of fishing gear permitted, but rather about quotas. Fishermen feel that new schemes are constantly being generated to prevent them from accessing a place in the tourism sector. They complain, for example, that the law, which stipulates that in order to acquire a permit that they must have had prior experience in tourism and must present an expensive environmental impact study, and not have any close relatives already involved in the business, makes it extremely difficult for them to shift to tourism activities. In 2009, after years of waiting, some fishermen and local tour operators were granted permits to operate legally. The whole process was managed by the GNP and the Ministry of Tourism and is causing conflicts with the Park as some people feel that the licenses were not distributed in a fair manner. Many fishermen are disappointed with the process, claiming that it was merely a show to appease their sector. 


\section{The local tourism sector}

None of the socioeconomic sectors of the Galapagos described thus far represent an isolated and welldefined group of actors. Rather, most of these sectors are fluid and flexible with members of households involved in different economic activities. This flexibility means that people in the various sectors are constantly moving between sectors reorganizing their ties and strategies according to the present circumstances and to new economic developments. Perhaps one of the most dynamic, adaptable and fastest growing sectors in the Galapagos is that of small- and medium-scale businesses involved in tourism.

This sector is not only increasing in economic power but also in its political presence. The sector consists of tour operators, hotel owners, small- and medium-sized operators of overnight boat tours, operators of speed boats who travel between ports, local travel agencies, guides and other local people that are increasingly involved, directly or indirectly, with the growing number of tourists that stay in the port towns and spend their money locally. Most of these small- and medium-sized operators resent the fact that the large companies rarely use local services and that most tourists utilize the large boats, contributing little to the local economy. They share with the fishermen the belief that the conservation and science sectors have mostly benefited the large tourism industry and the interests of international groups that use the name of the Galapagos to make money at the expense of the local population. These smaller operators believe that they are the real conservationists, local people who understand the nature and the society of the islands. Contrary to the fishermen, however, many of the people involved in this sector are actively appropriating and using some of the key messages and symbols utilized by large tour companies and conservationists in order to expand their share of the market. The image of Darwin, the importance of the evolutionary process, the adaptations of native and endemic species, and the need to conserve the islands is part of their discourse. The Mayor of San Cristobal, for example, has erected two statues of Darwin in town, one in Frigatebird Cove, where Darwin first landed, and the other on the new boardwalk.

This emerging tourism is growing in both economic and political power as small- and medium-sized operations are expanding on the four populated Islands. The rapid growth of this sector, which has consequently contributed to the growth of the local economy, explains to a large extent the recent increase in the number of tourists coming to the Galapagos in spite of the fact that the total number of berths on liveaboard cruises has not increased. More and more tourists are staying for at least part of their visit in local hotels and accommodations and using local services such as day tours, restaurants, and local transportation. Some activities such as island hopping, which takes visitors from island to island in speedboats, are becoming popular with younger tourists.

One of their main complaints is that the cruise boats leave little money in the local economy. Studies made by the Charles Darwin Station show that of the US\$419 million spent by Galapagos tourists in 2007, only US\$62.9 million entered the local Galapagos economy (Epler, Watkins and Cardenas 2008). These studies also indicate that there is a concentration of the tourism infrastructure in few hands, as 45 individuals, companies, or families owned the 80 tour vessels operating in Galapagos, including luxury, standard, economy, and day-tour vessels (Epler and Prano 2008). Local politicians and some of the local residents often quote this numbers and demand a change in the type of touristic model used. The effort to conserve and in some cases shape the archipelago as a "natural laboratory" is being threatened mainly by the appeal of the Galapagos as a secular pilgrimage site for a public thirsty for pristine nature and scientific icons.

Concerned about the negative effects of the accelerated economic growth in the Galapagos, in April 2007, the Government of Ecuador officially declared Galapagos at risk from invasive species, rapidly expanding tourism and consequent growth in immigration, and made the conservation of the Islands a national priority. In June 2007, the Galápagos was added to UNESCO's list of World Heritage Sites in Danger. Ironically, the goal of having a prosperous and sustainable Galapagos based on ecotourism seems to be fading away.

A large part of the population is concerned that the Government, the owners of large tourism companies from Quito, and the National Park are increasingly talking about the need to regulate the local emergent tourism enterprises. They fear that new regulations will be passed to get the Islands removed from the UNESCO "endangered" list. What these local leaders and politicians are reacting against is a process of exclusion generated by the development of a tourism and conservation industry that has made the local people invisible, irrelevant and undesirable for the maintenance of Galapagos as a "natural laboratory".

\section{Conclusions}

The construct of the Galapagos as a "natural laboratory" is the product of a series of interconnected narratives composed over several centuries by pirates, whalers, explorers, scientists and conservationists. Starting in the 1950s, scientists and politicians realized that endogenous and exogenous pressures were threatening the archipelago and the species for which it had become famous. Management actions and conservation plans were implemented that sought to landscape the islands, restoring, preserving and recreating its wilderness to assure its viability as a "natural laboratory" and as a tourist destination. These efforts to shape the environment received financial support mainly from large international NGOs, government agencies of developed countries, the Ecuadorian government and from tourism revenues. 
The discourses that are generated by science and conservation and then used and marketed by the tourism sector are often rejected or appropriated by the fishermen and other residents of the Galapagos. Scientists are mostly outsiders who visit the Galapagos temporarily to collect information and data. Their work has generated the iconic Galapagos, and the global discourse that places it at the center of many biological and evolutionary controversies. Conservationists have based their efforts on the findings, debates and constructs of science, and have developed practices and actions to preserve the Galapagos as a "natural laboratory". Many of the owners of big tourism companies, who have marketed the Islands, are members and active participants of the conservation agencies that promote the efforts to maintain the Galapagos as pristine as possible. They believe that the model of tourism based on large and relatively expensive "floating hotels" is the best way to provide the income needed to manage and protect the archipelago. The fishermen, together with other members of the local residents, on the other hand, have opposed the imposition of the conservationist agenda and question the symbols and narratives used by this sector. The last important sector examined in this paper is that of the growing local tourism operators and managers, that share with the fishermen some of the criticisms of the large tourism industry and the conservationists. Nonetheless at the same time they use many of the key symbols and discourses that have been developed by scientists and the large tour operators.

As they engage in and contribute to the globalized discourses of conservation, biodiversity, and sustainable development, the different stakeholders are threatening the long-term viability of the natural resources that provide the environmental services that sustain them. While those involved in tourism have appropriated and used the idea of Galapagos as a pristine "natural laboratory" and a cradle of evolution, their very success could have unpredictable consequences. As opposition to the effort to keep the Galapagos pristine intensified, the discourses of conservation began to include words like "consensus", "participatory management" and "empowerment". Social issues have become an important concern of the Charles Darwin Foundation, NGOs, academicians and the GNP. However, many of the conservation initiatives still fail to include the local residents and fishermen and to take into account the complexities of the socioeconomic system which they are trying to manage (Gonzalez 2008). Most plans and schemes are imposed on the local people, who often feel marginalized, used and ignored.

Some conservationists still perceive and identify the local people, and particularly the fishermen, as the main problem, as they reject the symbols of conservation and science. Fishermen feel that conservationists and their allies have worked to control and restrict their daily activities, and that conservationists' main goal is not to protect nature, but to benefit economically from the projects and the money that they raise internationally in the name of the Galapagos. Local residents, affected in different ways by these globalized discourses and practices, have responded in diverse and paradoxical ways. Acts of symbolic resistance and paradigmatic reformulation have allowed them to adapt to new structuring strategies imposed on them by the government of Ecuador and by external organizations. At times these responses have consisted of acts of symbolic questioning and even of violent rejection. Often times, however, local people have responded by accommodating and appropriating the global discourse to create their own definitions of nature and conservation. Their creative engagement with these organizations occurs as they transform the fragile ecosystem, pressured by an increasingly globalized economic reality in which they are embedded. This globalized reality includes the demand for sea cucumber and shark fins. As the local population becomes more dependent on tourism there is an emergence and appropriation of new hybrid discourses as these groups begin to utilize the main symbols of science and conservation to further their particular cause. Local tour operators have also rejected some of the implications of conservation, but this growing and expanding sector of the society is learning how to use those same symbols for their own advantage. They use the image of Darwin and his saga, and of endemic animals and plants, to benefit from the expectations of tourists visiting the Islands.

As the different sectors involved with tourism become more important and manipulate the scientific and historic importance of the Islands, the flow of tourists continues to increase, creating uncertainties and challenges for the managers of the archipelago. The Galapagos is thus under the threat of becoming a victim of its own success as thousands of people annually visit the Islands to retrace the footsteps of Darwin and other scientists. The large number of tourists drawn to the Islands by the reputation of the Galapagos as a pristine "natural laboratory" is responsible, directly or indirectly, for many of the impacts that are eroding the conditions that make possible its existence. The Galapagos paradox is generated as the rising number of tourists creates the conditions that allow for more people to come to the Islands, importing lifestyles and patterns of consumption from the mainland; while at the same time, the funds generated by the tourists provide much of the resources necessary to resist openness through protected areas and Parks.

\section{References}

Adkin, L.E. 1992. Counter-hegemony and environmental politics in Canada. In W.K. Carroll (ed.) Organizing Dissent, pp. 137-156. Toronto: Garamond Press.

Agrawal, Arun and Elinor Ostrom. 2001. Collective action, property rights, and decentralization in resource use in India and Nepal. Politics \& Society 29 (4): 495-514. 
Bremner, J. and Jaime Perez 2002. A case study of human migration and the sea cucumber crisis in the Galapagos Islands. Ambio 31(4): 306-310.

Bishop, K, N Dudley, A Phillips, and S Stolton. 2004. Speaking a common language: the uses and performance of the IUCN system of management categories for Protected Areas. Cardiff, UK: Cardiff Univ., IUCN, UNEP-WC.

Brosius, J. Peter 1999. Green dots, pink hearts: displacing politics from the Malaysian rainforest. American Anthropologist 101 (1): 36-57.

Brothers, TS. 1997. Deforestation in the Dominican Republic: a village level view. Environmental Conservation. 24: 213-123.

Burnham, P. 2000. Indian Country, God's Country: Native Americans and national parks. Washington, DC: Island Press.

Carrier, James and Donald Macleod. 2005. Bursting the bubble: the socio-cultural context of ecotourism. Journal of the Royal Anthropological Institute 11: 315-334.

Carroll, W. K. 2006. Hegemony and counter-hegemony in a global field. Social Justice Studies 1 (1): 36-66. http://ojs.uwindsor.ca/ojs/leddy/index.php/SSJ/issue/view/44

Castrejón, Mauricio. 2008. El sistema de co-manejo pesquero de la GMR: situación actual, retos y perspectivas de cambio. Santa Cruz, Galápagos: Fundacion Charles Darwin and the Tinker Foundation.

Cohen, E. 1988. Authenticity and commoditization of tourism. Annals of Tourism Research 15: 371-86.

Elliot, Robert. 1997. Faking nature: the ethics of environmental restoration. New York: Routledge.

Epler, Bruce. 2007. Tourism, the economy, population growth and conservation in Galapagos. Document Submitted to the Charles Darwin Research Station. Puerto Ayora.

Epler, Bruce and Maria Eugenia Proano. 2008. How many tourists can Galapagos accommodate? In Galapagos Report 2006-2007, pp. 36-41. Puerto Ayora, Galapagos, Ecuador: CDF, GNP and INGALA.

Errington, Frederick and Deborah B Gewertz. 2003. Tourism and anthropology in a post-modern world. Reprinted in Gmelch, Sharon (ed.) Tourists and Tourism. New York: Waveland.

Escobar, A. 1995. Encountering development: the making and unmaking of the third world Princeton, NJ: Princeton University Press.

Finchum, Ryan. 2002. The beliefs and perceptions of fishermen regarding management actions, regulations, and the protection of the Galapagos Marine Reserve, Ecuador. MS thesis, Colorado State University and also prepared for the Galapagos National Park Service and the Charles Darwin Research Station.

García Canclini, N. 1989. Culturas híbridas: estrategias para entrar y salir de la modernidad. México: Grijalbo.

Gillison G. 1980. Images of nature in Gimi thought. In MacCormack C. and M. Strathern (eds.) Nature, culture and gender, pp. 143-173. Cambridge, UK: Cambridge University Press.

Grenier, Christophe. 2007. Conservación Contra Natura. Quito: Abya Yala.

González, Jose, Carlos Montes, José Rodríguez and Washington Tapia. 2008. Rethinking the Galapagos Islands as a complex social-ecological system: implications for conservation and management. Ecology and Society 13.[online] URL: http://www.ecologyandsociety.org/vol13/iss2/art13/

Hall, S. 1988. The hard road to renewal. London: Verso.

Hearn, Alex, Juan Carlos Murillo and Harry Reyes. 2008. Declining profitability of fisheries in the Galapagos Marine Reserve. In: Galapagos Report 2006-2007, pp. 19-35. Puerto Ayora, Galapagos, Ecuador: CDF, GNP, and INGALA.

Heslinga, J.D. 2003. Regulating ecotourism in Galapagos: case study of domestic international partnerships. Journal of international wildlife law and policy 6: 57-77.

Heylings, P and M. Bravo. 2007. Evaluating governance: a process for understanding how co-management is functioning, and why, in the Galapagos Marine Reserve. Ocean \& Coastal Management. 50: 174-208.

Igoe, Jim. 2003. Conservation and globalization: a study of national parks and indigenous communities from East Africa to South Dakota. Wadsworth Publishing.

Johnson, LM. 2000. A place that's good: Gitksan landscape perception and ethnoecology. Human Ecology. 282: 301-25.

Kerr, Suzi, Susana Cardenas, and Joanna Hendy. 2004. Migration and the environment in the Galapagos: an analysis of economic and policy incentives driving migration, potential impacts from migration control, and potential policies to reduce migration pressure. Motu Working Paper 03-17. Wellington, New Zealand: Motu Economic and Public Policy Research.

Kottak, Conrad. P. 1999. The new ecological anthropology. American Anthropologist 101(1): 23-35. 
Larson, Edward. 2001. Evolution's Workshop: God, Science on the Galapagos. London: Penguin Books.

Latorre, O. 1992. El hombre en las islas encantadas: la historia humana de Galápagos. Quito: Producción Grafica.

MacCannell, D. 1973. Staged authenticity: arrangements of social space in tourist settings. American Journal of Sociology 79: 589-603.

MacKay, F and E. Caruso. 2004. Indigenous lands or national parks? Cultural Survival. 28(1):14.

Nichols, H. 2006. Lonesome George: the life and loves of a conservation icon. Palgrave Macmillan.

Nugent, S.1994. Big Mouth: the Amazon speaks. San Francisco: Brown Trout Press.

Oleas, Reyna. 2008. Costo de la entrada al Parque Nacional Galápagos: ¿Se debe incrementar? In Galapagos Report 2007-2008. Puerto Ayora, Galapagos, Ecuador: CDF, GNP and INGALA.

Ordóñez, Alejandra. 2008. Situación de la oferta turística en Galápagos: Planta turística, capacidad instalada y capacidad de acogida. In Informe Galápagos 2007-2008, pp.86-90. Puerto Ayora, Galapagos, Ecuador: CDF, GNP and INGALA.

Ospina, Pablo. 2006. Galápagos, naturaleza y sociedad: actores sociales y conflictos ambientales. Corporación Editora Nacional Quito.

Peluso, N.L. 1993. Coercing conservation: the politics of state resource control. Global Environmental Change 3 (2):199-218.

Preston, D. and M. Preston. 2006. A pirate of exquisite mind: explorer, naturalist, and buccaneer: the life of William Dampier. New York: Walker.

Proaño, Maria Eugenia and Bruce Epler. 2008. Tourism in Galapagos: a strong growth trend. In Galapagos Report 2006-2007, pp. 31-35. Puerto Ayora, Santa Cruz, Galapagos: CDF, GNP and INGALA.

Quiroga, D. 2009. Galápagos, laboratorio natural de la evolución: una aproximación histórica. ciencia para la sostenibilidad en Galápagos. In Tapia et al. (eds.). Ciencia para la sostenibilidad de Galápagos. pp. 13-61. Pt. Ayora, Galapagos: Parque Nacional Galápagos.

Quiroga, D and P. Ospina. 2009. Percepciones sociales sobre la ciencia y los científicos en Galápagos. In Tapia et al. (eds.). Ciencia para la sostenibilidad de Galápagos. pp. 109-126. Pt. Ayora, Galapagos: Parque Nacional Galápagos.

Santander, Garcia Tatiana. 2007. Evolución de la investigación científica en Galápagos y sus implicaciones en el manejo y conservación del Parque Nacional y la Reserva Marina. Masters Thesis, Universidad Autónoma de Madrid.

Scoones, I. 1999. New ecology and the social sciences: what prospects for a fruitful engagement? Annual Reviews of Anthropology. 28: 479-507.

Shiva, Vandana. 1988. Staying alive: women, ecology and development. London: Zed.

Stirrat, R.L. 1996 The new orthodoxy and old truths: participation, empowerment and other buzz words. In Sunil Bastian and Nicola Bastian (eds.) Assessing participation: a debate from South Asia. Delhi: Konark Publishers.

Sulloway, F.J. 1984. Darwin and the Galapagos. Biological Journal of the Linnaean Society 21:29-59.

Tye, Alan. 2006. Can we infer island introduction and naturalization rates from inventory data? Evidence from introduced plants in Galapagos. Biological Invasions 8: 201-215.

Villa, Angel. 2008. Vehicles in Galapagos. In Galapagos Report 2006-2007, pp. 73-80 Puerto Ayora, Galapagos: CDF, GNP, and INGALA.

Walker, B., S. Carpenter, J. Anderies, N. Abel, G. S. Cumming, M. Janssen, L. Lebel, J. Norberg, G. D. Peterson, and R. Pritchard. 2002. Resilience management in social-ecological systems: a working hypothesis for a participatory approach. Conservation Ecology 6(1): 14. http://www.consecol.org/vol6/iss1/art14/.

Watkins, G. and F. Cruz. 2007. Galápagos en riesgo: un análisis socioeconómico de la situación actual en el archipiélago. Puerto Ayora, Galápagos: Fundación Charles Darwin.

Watkins, Graham y Alejandro Martinez. 2008. El cambiante marco organizacional en Galápagos. En Informe Galápagos 2007-2008, pp.62-71. Puerto Ayora, Galapagos, Ecuador: CDF, GNP and INGALA.

Weiner, Jonathan.1995. The beak of the finch: a story of evolution in our time New York: Vintage Book Edition.

West, Paige and James Carrier. 2004. Ecotourism and authenticity: getting away from it. Current Anthropology 45 (4): 483-491.

West, Paige, Dan Brockington and Jim Igoe. 2006. Parks and peoples: the social effects of protected areas. Annual Review of Anthropology 35 (1): 251-277. 
Wilshusen P, S.R. Brechin, C. Fortwangler, P. West. 2002. Reinventing a square wheel: a critique of a resurgent protection paradigm in international biodiversity conservation. Society and Natural Resources 15: 17-40.

Wilshusen, P. 2003. Exploring the political contours of conservation: a conceptual view of power in practice. In Brechin et al. (eds.) Contested nature: promoting international biodiversity with social justice in the twenty century. New York: University of New York Press.

Zapata, Carlos. 2005. Informe entre el conflicto y la colaboración: el manejo participativo en la Reserva Marina de Galápagos. Sistematización, evaluación y factores de éxito del modelo participativo. Fundación para el Desarrollo Alternativo Responsable para Galápagos FUNDAR Galápagos.

\begin{abstract}
Since Charles Darwin's famous visit to the Galapagos the reputation of the archipelago has been growing in the Western imagination as a place where one can study and understand evolutionary processes. Scientists who were concerned with collecting and classifying animals and plants from the Galapagos, with the support of UNESCO and other international organizations and universities, created the Charles Darwin Foundation in 1959. That same year, the Ecuadorian Government founded the Galapagos National Park, in charge of protecting 97\% of the Archipelago's terrestrial area. Since its beginning the GNP sought to restore degraded ecosystems and thus craft a "natural laboratory". Part of the plan to protect the flora and fauna of the Islands included the creation of a large tourism industry based on cruises that go from island to island. Conservationists' efforts in the 1980s and 1990s focused on protecting the oceans around the Galapagos and controlling and managing fishing for sea cucumbers, lobsters and sharks. Local people, and in particular the fishermen, resisted the efforts made by the government, conservationists, and the booming and powerful tourism industry, to impose a globalized conservation strategy and discourse and to control and limit local residents' activities. They developed new forms of resistance, appropriation and negotiation to deal with the government and the different conservation organizations. As extractive activities became illegal and criminalized and as fishing became less important from an economic point of view, local people, including the fishermen, began to view tourism as an important alternative economic pursuit. During the late 1990s new decision making bodies emphasized consensus and instituted a participatory management system in the Galapagos Marine Reserve. These organisms were not entirely successful, however, and conflicts and tensions reemerged after their creation. Despite their participation in these organisms, many local people felt ignored and marginalized while many managers and conservationists felt that locals, and especially the fishermen, had been abusing the system and the management process. The "Galapagos Paradox" results from a process by which the very same conditions that cause the Galapagos to attract the attention of scientists, conservationists and of tourists, are being put at risk by the success of its reputation and the increasing number of residents and visitors. These visitors and residents threaten the isolation of the archipelago, which has been critical in maintaining the uniqueness of the islands.
\end{abstract}

Key words: Galapagos, national park, conservation, resistance, fishing.

\title{
Résumé
}

Depuis la visite de Charles Darwin aux îles Galapagos, leur réputation a grandi dans l'imaginaire occidental comme un lieu où l'on peut étudier et comprendre l'évolution. Avec le soutien de l'UNESCO et d'autres organisations internationales et les universités, les scientifiques ont créé la Fondation Charles Darwin en 1959. Cette même année, le gouvernement Equatorien a fondé le Parc National des Galapagos, en charge de la protection de $97 \%$ de la superficie terrestre de l'archipel. Depuis son début, le PNB a cherché à restaurer les écosystèmes dégradés et de créer un «laboratoire naturel». Une partie du plan visant à protéger la flore et la faune des îles comprenait la création d'une industrie touristique basée sur des croisières qui vont d'île en île. Les efforts de défendeurs de l'environnement dans les années 1980 et 1990 visent à protéger les océans entourant les Galapagos et le contrôle et la gestion de la pêche pour les concombres de mer, les homards et les requins. Les populations locales, et en particulier les pêcheurs, a résisté les efforts déployés par le gouvernement, les écologistes et l'industrie du tourisme, d'imposer une stratégie de conservation de la mondialisation et du discours et de contrôler et limiter les activités des résidents locaux. Ils ont développé de nouvelles formes de résistance, d'appropriation et de négociation pour traiter avec le gouvernement et les organisations de conservation. Alors que les activités extractives sont devenues illégales et de la pêche est devenue moins grande importance économique, les populations locales (y compris les pêcheurs) ont commencé à considérer le tourisme comme une solution économique. Nouvelles institutions en place un système de gestion participative dans la Réserve marine des Galapagos. Ces efforts n'ont pas été entièrement couronné de succès, les conflits et les tensions ont resurgi. Un système de gestion participative a été commencé dans la Réserve Marine. Cela n'a pas été entièrement un succès, et les conflits et les tensions ont resurgi. Beaucoup de personnes locales se sont senties marginalisées ou ignorées alors que de nombreux gestionnaires et les écologistes croient que les populations locales, et notamment des pêcheurs, avaient abusé le système et les processus de gestion. Le «Galapagos Paradox» résulte d'un processus par lequel les conditions mêmes qui provoquent les Galapagos pour attirer l'attention des scientifiques, les écologistes, les 
touristes et les migrants, sont mises en péril par le succès de sa réputation. Ces visiteurs et les résidents menacent l'isolement de l'archipel, qui a joué un rôle crucial dans le maintien de l'unicité des îles.

Mots-clés: Galapagos, parc national, conservation, résistance, la pêche.

\section{Resumen}

Después de la famosa visita de Carles Darwin a las Galápagos, la reputación de este Archipiélago como un laboratorio natural, un lugar en el cual la evolución puede ser estudiada en estado natural, creció en el imaginario Occidental. Los científicos que en un principio estaban interesados en la recolección de especies de animales y plantas, juntos con la UNESCO y el apoyo de organismos y universidades internacionales, crearon la Fundación Científica Charles Darwin en 1959. En ese mismo año, el Gobierno de Ecuador creó el Parque Nacional Galápagos entidad encargada de proteger el 97\% de la zona terrestre de las Islas. Desde sus inicios el PNG buscó la restauración de los ecosistemas y esculpir el laboratorio natural. Parte de la estrategia para proteger los animales y plantas de las Islas consistió en la generación de una poderosa industria turística basada en los cruceros navegables que llevan a los turistas de una isla a otra. Los esfuerzos de los conservacionistas durante la década de los ochentas y noventas se dirigieron hacia los océanos alrededor de las Galápagos y la protección de los pepinos de mar, las langostas y los tiburones. Los residentes locales y especialmente los pescadores resistieron los esfuerzos de imponer estrategias y prácticas globalizadas y controlar y limitar sus actividades y el acceso a los recursos. Desarrollaron nuevas maneras de resistencia, apropiación y negociación frente a los conservacionistas y los administradores de las áreas protegidas. Conforme las actividades extractivistas son criminalizadas y la pesca se convierte en una actividad cada vez menos atractiva, los residentes locales, incluidos los pescadores ven el turismo como una importante actividad económica alternativa. Al final de la década de los noventa, nuevos organismos fueron creados para la toma de decisiones concernientes al manejo de la Reserva Marina de Galápagos basados en la búsqueda de consensos y el manejo participativo. Estos organismos han sido solamente parcialmente exitosos y los conflictos y las tensiones emergieron nuevamente después de la creación y de estos cuerpos colegiados. La paradoja de Galápagos se genera cuando las condiciones que han atraído a científicos, conservacionistas y turistas a este prístino laboratorio natural donde los procesos evolutivos pueden ser observados y estudiados, son amenazados por la creciente reputación del archipiélago la cual genera un creciente número de visitantes que amenazan el aislamiento insular el cual es critico para mantener la singularidad del archipiélago.

Palabras clave: Galápagos, parque nacional, la conservación, la resistencia, la pesca. 